\title{
Prostate Cancer pT3 TNM Finding v6 and v7
}

National Cancer Institute

\section{Source}

National Cancer Institute. Prostate Cancer pT3 TNM Finding v6 and v7. NCI Thesaurus.

Code $C 48240$.

Prostate cancer with extraprostatic extension. (from AJCC 6th and 7th Eds.) 